\title{
PHOSPHORUS REMOVAL FROM PIGGERY EFFLUENTS OF VARYING QUALITY USING LIME AND PHYSICO-CHEMICAL TREATMENT METHODS
}

\author{
D. M. Weaver \& G. S. P. Ritchie
}

\begin{abstract}
The choice of management practices for the treatment of piggery effluent prior to its disposal to waterways or land is governed by the desire to simultaneously minimise the cost of treatment whilst minimising pollution of the environment. Laboratory experiments were conducted to compare the removal of total and total filterable phosphorus $(P)$ $(<0.45 \mathrm{\mu m})$ from ortho-phosphate solutions or piggery effuent by hydrated lime or lime kiln dust alone, or from recycled piggery effluent by lime and physico-chemical treatment methods. In addition, the ability of lime to remove $P$ from recycled piggery effuent at an intensive piggery was assessed.

Most $P$ in lime treated effluent was present in the $>0.45 \mu \mathrm{m}$ fraction because of the presence of unsettled flocs of $P$ impregnated lime. The efficiency of total $P$ removal by hydrated lime and lime kiln dust decreased as effluent quality declined. The efficiency of removal of total fliterable $P$ by hydrated lime or lime kiln dust was not affected by effluent quality. Hydrated lime was more efficient in removing $P$ from effluent or ortho-phosphate solutions, but lime kiln dust was more cost effective. More than $95 \%$ of total $P$ was removed from recycled piggery effluent when physico-chemical treatment followed settling with or without lime. The physico-chemical treatment decreased total $P$ mainly by decreasing the number of suspended particles in the effluent and by precipitating some total filterable $P$ as iron, aluminium or calcium compounds.
\end{abstract}

\section{INTRODUCTION}

Point sources of phosphorus (P) such as intensive piggeries can contribute significantly to the eutrophication of waterways (Raper, 1983; Sas, 1989). The choice of management practices for the treatment of piggery effluent prior to its disposal is governed by the need to simultaneously minimise the cost of treatment whilst minimising impacts on the environment. Effluent disposal methods include spray irrigation onto soils or treatment to remove $\mathrm{P}$, nitrogen $(\mathrm{N})$ and some heavy metals (Raper, 1983). In the latter approach, lime has been used to remove phosphorus (Raper, 1983), but bauxite residues (Weaver \& Ritchie, 1987) and iron and aluminum compounds have also been investigated.

Previous work has compared the ability of different limes to remove $\mathbf{P}$ from piggery effluent, (Weaver \& Ritchie, 1987). The work focused on the removal of filterable $\mathrm{P}(<0.45 \mu \mathrm{m})$ and did not consider whether the properties of the effluent itself affected the efficiency of $\mathrm{P}$ removal by the lime. Both of these factors are important when applying the above research to effluents of different quality, particularly since the chemical characteristics of piggery effluent have been found to vary quite widely (Payne, 1986a). In addition, effluent properties will continue to change as producers reduce costs by conserving water and recycling effluent (Gray et al. 1991).

Furthermore, experiments at an intensive piggery have indicated that flocs of lime impregnated with $\mathrm{P}$ may remain suspended after chemical treatment. Therefore, removal of these flocs may improve the clarity and decrease the $\mathrm{P}$ concentration of the treated effluent.

The objectives of this work were (i) to compare the removal of total $\mathrm{P}$ (TP) and total filterable $\mathrm{P}$ from ortho-phosphate $\left(\mathrm{KH}_{2} \mathrm{PO}_{4}\right)$ solutions or piggery effluent in the laboratory by hydrated lime or lime kiln dust, (ii) to assess the ability of lime to remove $P$ from recycled piggery effluent at an intensive piggery, and (iii) to assess the removal of TP and total filterable $P$ from recycled piggery effluent by lime and physico-chemical treatment methods.

\section{MATERIALS AND METHODS}

Experiment 1-ortho-phosphate reactions with lime in the laboratory

Hydrated lime and lime kiln dust (physico-chemical properties outlined in Weaver and Ritchie (1987)) were used to remove $\mathrm{P}$ from ortho-phosphate $\left(\mathrm{KH}_{2} \mathrm{PO}_{4}\right)$ 
solutions of different initial $\mathbf{P}$ concentrations and solution : lime ratios. The initial $P$ concentrations were 40 , 60,80 and $100 \mathrm{mg} \mathrm{litre}^{-1}$. The solution: lime ratios used for hydrated lime were $200: 1(\mathrm{ml}: \mathrm{g}), 400: 1,600: 1,800: 1$ and $1000: 1$, and for lime kiln dust were $50: 1,150: 1$, $300: 1,600: 1$ and $900: 1$. The range of ratios used for lime kiln dust was smaller because it was known to be less efficient at removing $P$ from piggery effluent than hydrated lime (Weaver \& Ritchie, 1987). Three replicates of each treatment combination were shaken end over end for $30 \mathrm{~min}$ at $20^{\circ} \mathrm{C}$. Each sample was then centrifuged and the supernatant was filtered through a 0.45 $\mu \mathrm{m}$ filter. $\mathrm{pH}$ and $\mathrm{P}$ were determined on the filtered solutions according to John (1970).

\section{Experiment 2-Reactions of piggery effluent with lime in the laboratory}

Non-recycled piggery effluent was dosed with various quantities of either hydrated lime or lime kiln dust to achieve effluent:lime ratios of $50: 1(\mathrm{ml}: \mathrm{g}), 100: 1,200: 1$, $400: 1,700: 1,1000: 1$ and $1400: 1$ in a single dose. The effluent contained 153 and $34 \mathrm{mg}$ litre $^{-1}$ of TP and total filterable P (i.e. TP determined on effluent filtered through a $0.45 \mu \mathrm{m}$ filter), respectively. Each sample was mixed and allowed to settle in a cylindrical vessel $(65 \mathrm{~mm}$ diameter by $150 \mathrm{~mm}$ high) and the height of the sludge interface was measured at 5 min intervals to determine the settling rate. Settling was calculated by expressing the sludge height as a percentage of the height of the lime/ effluent mixture. The supernatant was subsampled after 1 and $48 \mathrm{~h}$ and analysed for $\mathrm{pH}$ and TP. Total filterable $P$ was determined on the $1-h$ subsamples. Phosphorus was determined using the method of John (1970) or Hanson (1950) depending on the concentration. Effluent samples were digested with perchloric acid (AOAC, 1984).

\section{Experiment 3-Reactions of recycled piggery effluent with lime at a piggery}

Non-recycled piggery effluent was recycled through a complex (Fig. 1(a)) that housed 2000 pigs and produced an estimated 27000 litres of effluent daily.

Effluent recycling was a normal part of piggery operation. Recycling was controlled by a computer system that preferentially flushed waste from waste channels that had the highest excrement loading. The effluent flowed to the centre of the shed, drained to a sump, and was agitated and pumped over a screen to remove some of the solids. The effluent was then recycled for further flushing. As this process continued, the effluent volume would increase as pigs urinated and defecated and water from drinkers was spilt. Towards the end of the day, the effluent stream was diverted after screening to another tank in preparation for lime dosing.

Larger volumes of effluent were recycled in preparation for dosing with hydrated lime than lime kiln dust in order to produce sufficient quantities of lime residue for other experiments.

Lime kiln dust or hydrated lime were mixed with recycled effluent at the ratio for each predetermined treatment (Table 1) as it entered the treatment tank

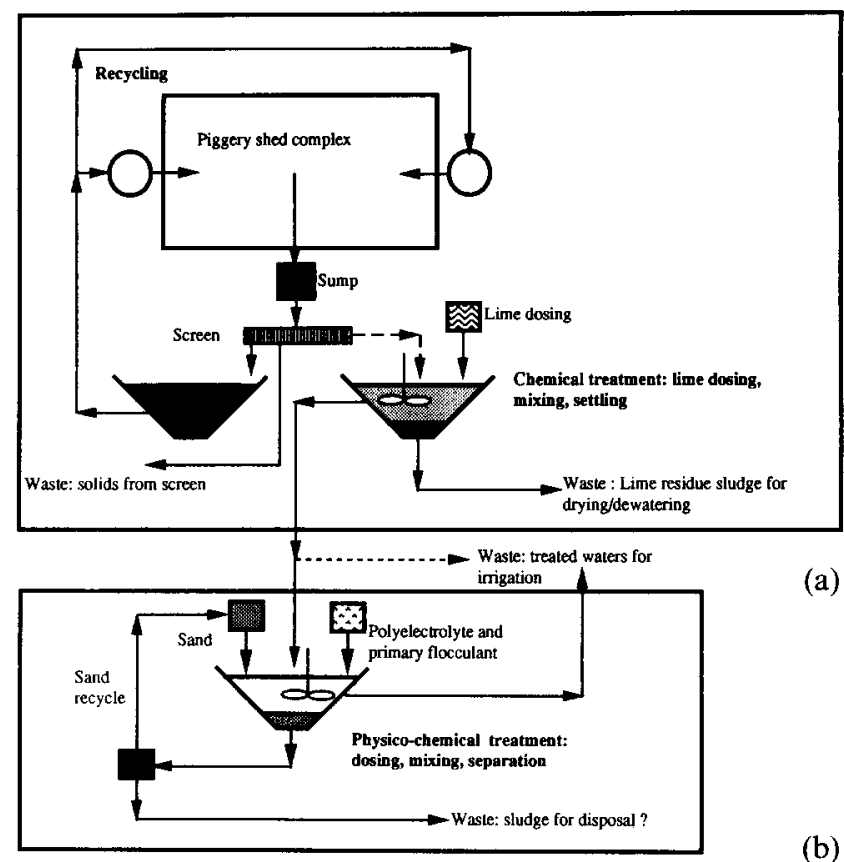

Fig. 1. Schematic diagram showing (a) effluent recycling and lime dosing procedure, and (b) conceived physio-chemical treatment procedure.

after screening. A pump was used to mix the lime and effluent thoroughly before settling overnight (16-20 h). Samples of screened solids, non-recycled effluent, recycled effluent and recycled lime-treated effluent (supernatant after settling) were taken and analysed for TP and total filterable $P$, as described previously. Phosphorus in the $>0.45 \mu \mathrm{m}$ fraction was estimated by difference. Total solids was determined in each liquid sample by evaporation (APHA, 1978). Efficiency of P removal by each type of lime was assessed by comparing the TP removed per unit lime dose and cost effectiveness was assessed by comparing the TP removed per unit cost of lime.

Experiment 4-Phosphorus removal from recycled and lime treated piggery effluent using a physico-chemical treatment method in the laboratory

\section{Phase 1}

A subsample of recycled effluent was collected, thoroughly mixed and separated into equal volumes in preparation for lime treatment.

\section{Phase 2}

Lime kiln dust was then added at rates of $0,0.75,2.25$, or $3.75 \mathrm{~g} \mathrm{litre}^{-1}$, thoroughly mixed with the effluent, and allowed to settle overnight $(16 \mathrm{~h})$.

\section{Phase 3}

The supernatant was removed and then subjected to a physico-chemical treatment (EPA, 1990; Inert Particle Collection, IPC $\dagger)$ using sand, polyelectrolyte $(0$ $20 \mathrm{mg} \mathrm{litre}^{-1}$ ) and a primary flocculant. The primary flocculants were alum (150-350 $\mathrm{mg} \mathrm{A1}^{3+}$ litre $\left.^{-1}\right)$, ferric

+ The use of this procedure does not indicate endorsement by the authors. This treatment was merely used to demonstrate the effect of removing particulates on $\mathrm{P}$ concentrations. 
Table 1. Experiment 3-P as total, total filterable or in the $>0.45 \mu \mathrm{m}$ fraction for non-recycled, recycled and for lime treated-recycled piggery effluent

\begin{tabular}{|c|c|c|c|c|c|c|}
\hline \multirow[t]{2}{*}{ Effluent sample } & \multirow[t]{2}{*}{ Lime type } & \multirow[t]{2}{*}{$\begin{array}{l}\text { Effluent : lime } \\
\text { ratio } \\
(\mathrm{ml}: \mathrm{g})\end{array}$} & TP & $\begin{array}{c}\text { Total } \\
\text { filterable } \mathrm{P}\end{array}$ & $\begin{array}{l}\text { Total } \\
\text { solids }\end{array}$ & $\begin{array}{l}P \text { in } \\
>0.45 \mu \mathrm{m} \\
\text { fraction }\end{array}$ \\
\hline & & & \multicolumn{4}{|c|}{$\left(\mathrm{mg}\right.$ litre $\left.^{-1}\right)$} \\
\hline Non-recycled & & & 62 & 62 & 4000 & 0 \\
\hline Recycled & & & 219 & 96 & 7700 & 123 \\
\hline Treated-recycled & Lime kiln dust & 131 & 103 & 3 & 4500 & 100 \\
\hline Non-recycled & & & 72 & 47 & 2200 & 25 \\
\hline Recycled & & & 201 & 83 & 8100 & 118 \\
\hline Treated-recycled & Lime kiln dust & 88 & 24 & 2 & 4300 & 22 \\
\hline Non-recycled & & & 81 & 56 & 3700 & 25 \\
\hline Recycled & & & 90 & 62 & 4200 & 28 \\
\hline Treated-recycled & Hydrated lime & 743 & 66 & 4 & 4300 & 62 \\
\hline Non-recycled & & & 83 & 45 & 3200 & 37 \\
\hline Recycled & & & 138 & 54 & 6000 & 83 \\
\hline Treated-recycled & Hydrated lime & 385 & 35 & 4 & 5100 & 31 \\
\hline
\end{tabular}

chloride (300-500 $\mathrm{mg} \mathrm{Fe}^{3+}$ litre $^{-1}$ ), ferric sulphate (200$400 \mathrm{mg} \mathrm{Fe}{ }^{3+}$ litre $\left.^{-1}\right)$ or hydrated lime (5000-10 $000 \mathrm{mg}$ litre $\left.^{-1}\right)$. The procedure for treating the effluent after lime dosing is conceptualised in Fig. 1(b).

Samples of the recycled effluent (phase 1), lime treated effluent (phase 2) and effluent treated with lime and with IPC (phase 3) were retained for analysis. Each sample was analysed for total $\mathrm{P}$ and some were analysed for total filterable $\mathrm{P}$ and $\mathrm{pH}$. Aluminium was determined on samples in which alum was used as the primary flocculant (Dougan \& Wilson, 1974). The solids resulting from settling (phase 2) were collected, dried at $50^{\circ} \mathrm{C}$ and analysed for total $\mathbf{P}$ and neutralising value (AOAC, 1984).

\section{RESULTS}

Experiment 1-ortho-phosphate reactions with lime in the laboratory

Mixing ortho-phosphate solutions with lime caused the $\mathrm{pH}$ to decrease as the solution:lime ratio increased (Fig. 2). The decrease in $\mathrm{pH}$ was greatest for lime kiln dust at $\mathrm{P}$ concentrations $>40 \mathrm{mg}$ litre $^{-1}$. For lime kiln

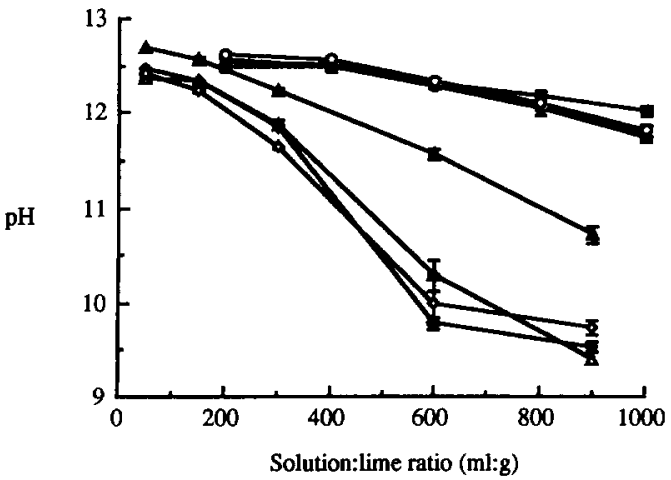

Fig. 2. Experiment $1-\mathrm{pH}$ as a function of solution: lime ratio $(\mathrm{ml}: \mathrm{g})$ for hydrated lime in contact with a $(\square) 40$, ( $\square$ ) $60,(O) 80$ and $(O) 100 \mathrm{mg}$ litre $^{-1} \mathrm{P}$ solution and for lime kiln dust in contact with a $(\Delta) 40,(\Delta) 60,(\diamond) 80$ and $(\diamond)$ $100 \mathrm{mg}$ litre $^{-1}$ ) P solution. (Bars show standard errors.) dust, the $\mathbf{P}$ concentration remaining in solution was greater than the limits of detection $\left(<0.01 \mathrm{mg}\right.$ litre $\left.^{-1}\right)$ for the $80 \mathrm{mg} \operatorname{litr}^{-1} \mathrm{P}$ solution at solution: lime ratios $>600: 1$ and for the $100 \mathrm{mg} \mathrm{litre}^{-1} \mathrm{P}$ solution at solution : solid ratios $>300: 1$. For all other treatments of lime kiln dust and for all treatments of hydrated lime the $P$ remaining in solution was not detectable.

The $\mathrm{P}$ content of hydrated lime residue after mixing lime with ortho-phosphate solutions increased linearly with increasing solution: lime ratio. At a constant hydrated lime addition, the $\mathrm{P}$ content increased with increasing initial $\mathrm{P}$ concentration. The maximum $\mathrm{P}$ content attained was $10 \%$. The $\mathrm{P}$ content of hydrated lime residues could be determined using the following equation for the range of initial $\mathbf{P}$ concentrations and ratios tested.

$$
\begin{aligned}
\mathrm{P} \text { content }(\%)= & 0.0001 \times \mathrm{P} \text { concentration }\left(\mathrm{mg} / \text { litre }^{-1}\right) \\
& \times \text { solution }: \text { lime ratio }(\mathrm{ml}: \mathrm{g})
\end{aligned}
$$

The $\mathrm{P}$ content of the lime kiln dust residue increased with increasing solution:lime ratio at each initial $\mathrm{P}$ concentration, however, the rate of increase declined at solution:lime ratios $>600: 1$, that is as the final $P$ concentration increased above detectable levels. The maximum $\mathrm{P}$ content attained in the lime kiln dust residue was about $6 \%$. The same equation could be used to determine the $\mathrm{P}$ content of lime kiln dust residues except when $P$ concentrations and solution:lime ratios exceeded $80 \mathrm{mg} \mathrm{litre}^{-1}$ and $600: 1$ concomitantly. The $\mathrm{P}$ content of lime kiln dust residues did not increase further when these $\mathbf{P}$ concentrations or solution: lime ratios were exceeded.

Experiment 2-Reactions of piggery effluent with lime in the laboratory

Phosphorus remaining as total or total filterable $\mathbf{P}$ increased as the effluent:lime ratio increased for either hydrated lime or lime kiln dust. At effluent:lime ratios $>1000: 1$ hydrated lime was more efficient than lime kiln dust at decreasing total $P$ in the effluent. At 


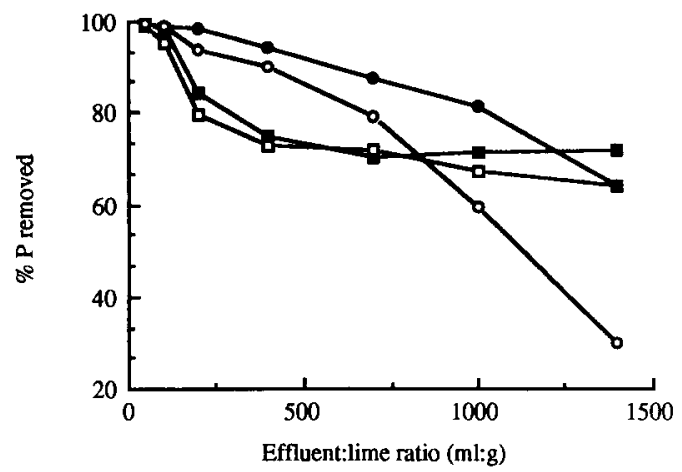

Fig. 3. Experiment 2 -phosphorus removed by $(\boldsymbol{\square}, \mathbf{O})$ hydrated lime, or $(\square, 0)$ lime kiln dust as a percentage of that initially present as TP (squares) or total filterable P (circles) at different effluent : lime ratios.

effluent: lime ratios $>200: 1$, hydrated lime was significantly $(P<0.05)$, more efficient than lime kiln dust at decreasing total filterable $P$ in the effluent (Fig. 3).

$\mathrm{pH}$ decreased rapidly up to effluent: lime ratios of 200:1 and then decreased more slowly at effluent: lime ratios $>200: 1$ for both hydrated lime and lime kiln dust (Fig. 4). In general, $\mathrm{pH}$ of hydrated lime treated effluent was higher than lime kiln dust treated effluent at the same ratio.

Phosphorus or total filterable $\mathrm{P}$ increased as $\mathrm{pH}$ decreased (Fig. 5). Phosphorus concentration decreased with increasing settling time and total filterable $\mathrm{P}$ was

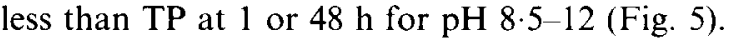

Settling of approximately $80 \%$ resulted after $50 \mathrm{~min}$ for effluent: lime ratios $\geq 400: 1$ for hydrated lime (Fig. 6(a)) and $\geq 200: 1$ for lime kiln dust (Fig. 6(b)). Nearly all of this settling was complete after $20 \mathrm{~min}$. At effluent: lime ratios of $\leq 200: 1$ for hydrated lime and $\leq 100$ : 1 for lime kiln dust, rapid settling for 20 min was followed by slower settling for the remaining $30 \mathrm{~min}$ (Fig. 6).

\section{Experiment 3-Reactions of recycled piggery effluent} with lime at a piggery

Total $\mathbf{P}$, total filterable $\mathbf{P}$ and total solids increased after recycling depending on the volume of effluent that was recycled (i.e. non-recycled versus recycled in Table 1). The increase was greatest where the least volume of

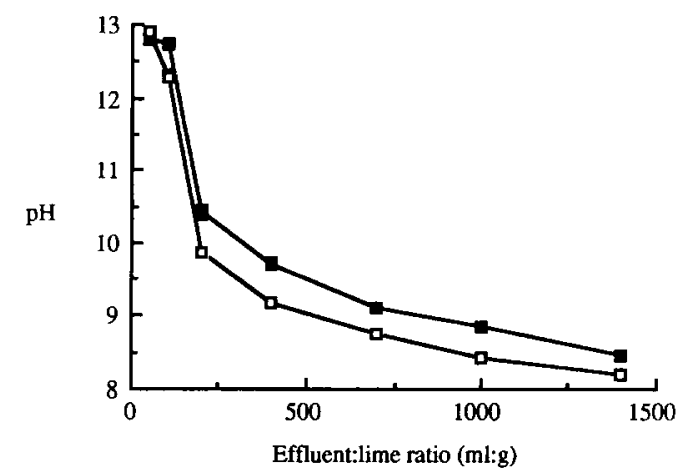

Fig. 4. Experiment $2-\mathrm{pH}$ as a function of effluent : lime ratio $(\mathrm{ml}: \mathrm{g})$ for $(\square)$ hydrated lime, and $(\square)$ lime kiln dust.

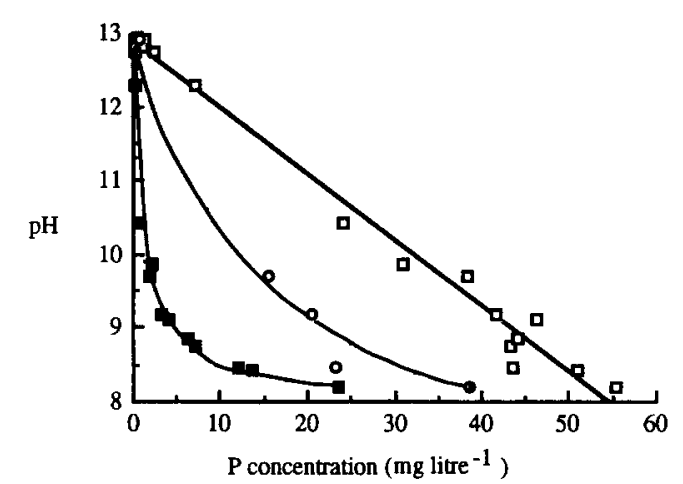

Fig. 5. Experiment $2-\mathrm{pH}$ as a function of $\mathrm{P}$ concentration (mg litre ${ }^{-1}$ ) independent of lime type for TP after $(\square) 1$ and (O) $48 \mathrm{~h}$ settling, and $(\square)$ for total filterable $P$.

effluent was recycled (i.e. lime kiln dust treatments) and least where the greatest volume of effluent was recycled (i.e. hydrated lime treatments). Total $P$ and total filterable $P$ decreased as a result of treating recycled effluent with either lime type (i.e. recycled versus treated-recycled in Table 1). Total filterable $\mathbf{P}$ decreased more than $93 \%$ and always decreased more than TP (Table 2). Lime kiln dust was more cost effective than hydrated lime for removal of TP, but hydrated lime was more efficient per unit lime dose at removing total $\mathbf{P}$ (Table 2). The $\mathbf{P}$ content of screened solids increased from 0.4 to $1.4 \%$ as a result of effluent recycling.

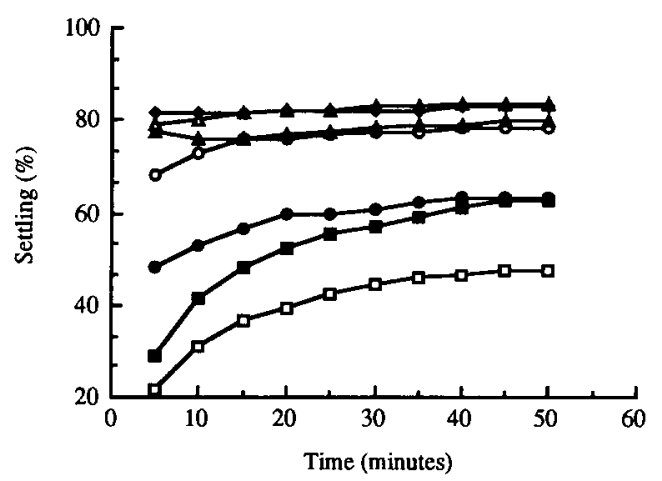

(a)

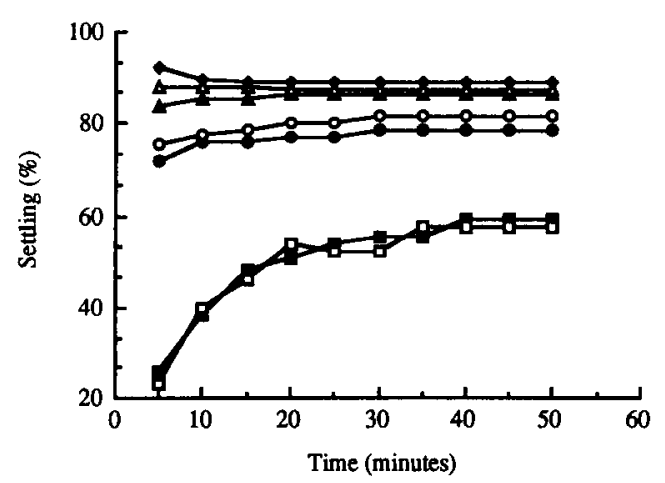

(b)

Fig. 6. Experiment 2-settling (\%) as a function of time for a $1 \mathrm{~g}$ dose of (a) hydrated lime, or (b) lime kiln dust for each

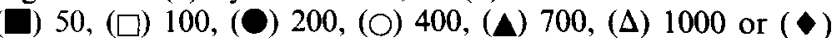
$1400 \mathrm{ml}$ of piggery effluent. 
Table 2. Experiment 3-percentage decrease in TP and total filterable $P$ and cost efficiency and effectiveness of lime dosing with different lime types

\begin{tabular}{lcccccr}
\hline Lime type & $\begin{array}{c}\text { Effluent:lime } \\
\text { ratio } \\
(\mathrm{ml}: \mathrm{g})\end{array}$ & $\begin{array}{c}\mathrm{Cost}^{\alpha} \\
\left(\$ \mathrm{pig}^{-1} \text { year }^{-1}\right)\end{array}$ & $\begin{array}{c}\text { Decrease in } \\
\text { Total P } \\
(\%)\end{array}$ & $\begin{array}{c}\text { Decrease in } \\
\text { total } \\
\text { filterable P } \\
(\%)\end{array}$ & $\begin{array}{c}\text { Decrease in } \\
\text { TP per } \\
\text { unit cost } \\
\left(\% \$^{-1}\right)\end{array}$ & $\begin{array}{c}\text { Decrease in } \\
\text { TP per } \\
\text { unit lime dose } \\
\left(\% \mathrm{~g}^{-1}\right)\end{array}$ \\
\hline Lime kiln dust & 131 & $1.00(1 \cdot 31)$ & 53 & 97 & 53 & 7 \\
Hydrated lime & 743 & $1.00(1.31)$ & 27 & 94 & 27 & 21 \\
Lime kiln dust & 88 & $1.50(1.96)$ & 88 & 98 & 58 & 8 \\
Hydrated lime & 385 & $1.90(2 \cdot 49)$ & 75 & 93 & 39 & 29 \\
\hline
\end{tabular}

" 1987 Australian dollars. Values in parentheses represent 1991 Australian dollars.

Experiments 1-3-Comparison of $P$ removal from effluents of different quality by lime

The efficiency of removal of TP by hydrated lime and lime kiln dust decreased with declining effluent quality (orthophosphate to non-recycled effluent to recycled effluent) when each lime type was compared at the same effluent: lime ratio (Table 3). The efficiency of removal of total filterable $\mathrm{P}$ by hydrated lime or lime kiln dust was not affected by effluent quality when each lime type was compared at the same effluent: lime ratio (Table 3 ).

Experiment 4 -Phosphorus removal from recycled and lime treated piggery effluent using a physico-chemical treatment method

Phase 2

Settling for $16 \mathrm{~h}$ without lime addition decreased TP and total filterable $P$ of recycled effluent up to 69 and $36 \%$, respectively (Tables 5 and 6 ). Increasing lime addition increased the removal of TP and total filterable $P$. The maximum removal of TP and total filterable $P$ through lime addition alone was 77 and $88 \%$, respectively.
Increasing lime addition decreased the $\mathbf{P}$ content, but increased the neutralising value of solids resulting from settling in phase 2 . The rate of increase in neutralising value with increased lime addition decreased with increasing initial TP concentration (Tables 4-6).

\section{Phase 3}

Settling with or without lime (phase 2) followed by IPC treatment (phase 3 ) removed $>95 \%$ of $\mathrm{TP}$ from recycled effluent. TP after phase 3 varied from $1 \cdot 1$ to $12.5 \mathrm{mg}$ litre $^{-1}$ (Tables 4-6) depending on the original TP in the effluent, the type and concentration of primary flocculant and the concentration of polyelectrolyte.

An increase in the amount of primary flocculant at a constant level of lime addition generally decreased TP (Tables 4-6). Total filterable $P$ in samples which had undergone IPC treatment was not determined because TP after IPC was markedly lower than total filterable P after lime treatment alone. Alum treated effluent had neutral $\mathrm{pH}$ and aluminium concentrations ranged from $22-52 \mu \mathrm{M}$.

Table 3. Experiments 1-3 - comparison of removal of $P$ from ortho-phosphate solutions, non-recycled and recycled effluent by lime at the same dosage rate

\begin{tabular}{|c|c|c|c|c|c|}
\hline Lime type & Effluent type & $\begin{array}{c}\text { Effluent : lime } \\
\text { ratio } \\
(\mathrm{ml}: \mathrm{g})\end{array}$ & $\begin{array}{l}\text { Initial P concentration } \\
\left.(\mathrm{mg} \mathrm{litre})^{-1}\right)\end{array}$ & $\begin{array}{l}\text { Final P concentration } \\
\left.(\mathrm{mg} \mathrm{litre})^{-1}\right)\end{array}$ & $\begin{array}{c}\text { Decrease in } \\
\mathrm{P} \\
(\%)\end{array}$ \\
\hline
\end{tabular}

Lime kiln dust

Lime kiln dust

Lime kiln dust

Hydrated lime

Hydrated lime

Hydrated lime

ortho-phosphate
Non-recycled
Recycled $^{c}$
ortho-phosphate
Non-recycled
Recycled $^{c}$

Recycled ${ }^{c}$ ortho-phosphate ${ }^{a}$

Non-recycled ${ }^{b}$

Recycled ${ }^{c}$

ortho-phosphate ${ }^{a}$

Non-recycled ${ }^{b}$

Recycled $^{c}$

131
131
131
743
743
743

131

131

743

743

743

TP

Lime kiln dust
Lime kiln dust
Hydrated lime
Hydrated lime
Hydrated lime

${ }^{a}$ Experiment 1.

${ }^{b}$ Experiment 2 .

$c$ Experiment 3. 
Table 4. Experiment 4 change in TP or total filterable $P$ after treatment with lime kiln dust with or without physico-chemical treatment using ferric chloride (as $\mathrm{Fe}^{3+}$ ) as the primary flocculant and, characteristics of settled solids after phase 2

\begin{tabular}{|c|c|c|c|c|c|c|c|c|c|}
\hline \multirow[t]{3}{*}{ Phase 1} & \multirow{3}{*}{$\begin{array}{l}\text { Phase } 2 \\
\text { Lime kiln } \\
\text { dust dose } \\
\left(\mathrm{g} \mathrm{litre}^{-1}\right)\end{array}$} & \multicolumn{2}{|c|}{ Phase 3} & \multirow[t]{3}{*}{$\begin{array}{c}\text { TP } \\
\left(\text { mg litre }^{1}\right)\end{array}$} & \multirow{3}{*}{$\begin{array}{l}\text { Total } \\
\text { filterable } \mathrm{P} \\
\text { (mg litre ') }\end{array}$} & \multirow{3}{*}{$\begin{array}{c}\text { Decrease } \\
\text { in TP } \\
(\%)\end{array}$} & \multirow{3}{*}{$\begin{array}{c}\text { Decrease } \\
\text { in total } \\
\text { filterable P } \\
(\%)\end{array}$} & \multirow{2}{*}{\multicolumn{2}{|c|}{$\begin{array}{c}\text { Characteristics of } \\
\text { solids produced in } \\
\text { phase } 2\end{array}$}} \\
\hline & & \multirow{2}{*}{$\begin{array}{c}\text { Primary } \\
\text { flocculant } \\
\text { dose } \\
\left(\mathrm{Fe}^{3+}\right) \\
\left(\mathrm{mg} \mathrm{litre}^{-1}\right)\end{array}$} & \multirow[b]{2}{*}{$\begin{array}{l}\text { Poly- } \\
\text { electrolyte } \\
\text { dose } \\
(m g \text { litre } \\
\left({ }^{-1}\right)\end{array}$} & & & & & & \\
\hline & & & & & & & & $\begin{array}{c}\mathrm{P} \\
\text { content } \\
(\%)\end{array}$ & $\begin{array}{c}\text { Neutralising } \\
\text { value } \\
(\%)\end{array}$ \\
\hline \multirow[t]{13}{*}{ Recycle } & \multirow{5}{*}{0.75} & & & $126 \cdot 5$ & $40 \cdot 3$ & & & & \\
\hline & & 0 & 0 & $66 \cdot 3$ & $22 \cdot 8$ & 48 & 43 & $2 \cdot 7$ & 21 \\
\hline & & 300 & 10 & 3.0 & $\mathrm{ND}^{a}$ & 98 & ND & & \\
\hline & & 400 & 10 & 1.7 & ND & 99 & ND & & \\
\hline & & 500 & 10 & $1 \cdot 1$ & ND & 99 & ND & & \\
\hline & \multirow{4}{*}{$2 \cdot 25$} & 0 & 0 & $54 \cdot 2$ & $13 \cdot 4$ & 57 & 67 & 1.9 & 46 \\
\hline & & 300 & 10 & 2.9 & ND & 98 & ND & & \\
\hline & & 400 & 10 & 1.6 & ND & 98 & ND & & \\
\hline & & 500 & 10 & $1 \cdot 1$ & ND & 99 & ND & & \\
\hline & \multirow[t]{4}{*}{3.75} & 0 & 0 & $53 \cdot 1$ & $8 \cdot 3$ & 58 & 80 & 1.5 & 58 \\
\hline & & 300 & 10 & $3 \cdot 1$ & ND & 98 & ND & & \\
\hline & & 400 & 10 & 1.8 & ND & 99 & ND & & \\
\hline & & 500 & 10 & 13 & ND & 99 & ND & & \\
\hline
\end{tabular}

${ }^{a}$ ND—not determined.

\section{DISCUSSION}

After chemical treatment with lime, most $P$ in treated effluent was present in the $>0.45 \mu \mathrm{m}$ fraction because of the presence of unsettled flocs of $\mathrm{P}$ impregnated lime. More than $95 \%$ of TP was removed from piggery effluent when physico-chemical treatment (experiment 4) followed settling with or without lime. Lime addition (phase 2) was not necessary to remove $>95 \%$ of the TP. The effects of the physico-chemical treatment process were two-fold: (i) to rapidly remove particles from solution, and (ii) to remove some total filterable $P$ as iron, aluminium or calcium salts. Total filterable $\mathrm{P}$ was removed by physico-chemical treatment because TP concentrations after physico-chemical treatment (phase 3) were significantly lower than total filterable P concentrations after lime dosing alone (phase 2).

Declining effluent quality reduced the efficiency of removal of TP by lime but not total filterable $\mathrm{P}$. Lime addition alone decreased total filterable $P$ of piggery effluent more than TP. It is possible that dissolved organic matter in the effluent was either competing with the $\mathrm{P}$ in the effluent for adsorption sites on the lime particles and had a greater affinity for them, or

Table 5. Experiment 4 -change in TP or total filterable $P$ after treatment with lime kiln dust with or without physico-chemical treatment using alum (as $\mathrm{Al}^{3+}$ ) as the primary flocculant and, characteristics of settled solids after phase 2

\begin{tabular}{|c|c|c|c|c|c|c|c|c|c|}
\hline \multirow[t]{3}{*}{ Phase 1} & \multirow{3}{*}{$\begin{array}{l}\text { Phase } 2 \\
\text { Lime kiln } \\
\text { dust dose } \\
\left(\text { g litre }^{1} \text { ) }\right.\end{array}$} & \multicolumn{2}{|c|}{ Phase 3} & \multirow{3}{*}{$\begin{array}{c}\text { TP } \\
\left.\text { (mg litre }{ }^{\prime}\right)\end{array}$} & \multirow{3}{*}{$\begin{array}{c}\text { Total } \\
\text { filterable } \mathbf{P} \\
\left.\text { (mg litre }^{-1}\right)\end{array}$} & \multirow{3}{*}{$\begin{array}{l}\text { Decrease } \\
\text { in TP } \\
(\%)\end{array}$} & \multirow{3}{*}{$\begin{array}{c}\text { Decrease } \\
\text { in total } \\
\text { filterable P } \\
(\%)\end{array}$} & \multirow{2}{*}{\multicolumn{2}{|c|}{$\begin{array}{c}\text { Characteristics of } \\
\text { solids produced in } \\
\text { phase } 2\end{array}$}} \\
\hline & & Primary & & & & & & & \\
\hline & & $\begin{array}{c}\text { flocculant } \\
\text { dose } \\
\left(\mathrm{Al}^{3+}\right) \\
\left(\mathrm{mg} \mathrm{litre}^{-1}\right)\end{array}$ & $\begin{array}{c}\text { Poly } \\
\text { electrolyte } \\
\text { dose } \\
\left(\mathrm{mg} \mathrm{litre}^{\mathrm{l}}\right)\end{array}$ & & & & & $\begin{array}{c}P \\
\text { content } \\
(\%)\end{array}$ & $\begin{array}{c}\text { Neutralising } \\
\text { value } \\
(\%)\end{array}$ \\
\hline \multirow[t]{17}{*}{ Recycle } & \multirow{5}{*}{0} & & & 333.4 & $44 \cdot 5$ & & & & \\
\hline & & 0 & 0 & $104 \cdot 7$ & $42 \cdot 4$ & 69 & 5 & $2 \cdot 4$ & 1 \\
\hline & & 150 & 15 & 4.4 & ND $^{\prime}$ & 99 & ND & & \\
\hline & & 200 & 15 & 3.0 & ND & 99 & ND & & \\
\hline & & 250 & 15 & $2 \cdot 0$ & ND & 99 & ND & & \\
\hline & \multirow[t]{4}{*}{0.75} & 0 & 0 & 87.4 & $30 \cdot 1$ & 74 & 32 & $2 \cdot 3$ & 6 \\
\hline & & 150 & 15 & $5 \cdot 6$ & ND & 98 & ND & & \\
\hline & & 200 & 15 & $4 \cdot 2$ & ND & 99 & ND & & \\
\hline & & 250 & 15 & $2 \cdot 2$ & ND & 99 & ND & & \\
\hline & \multirow[t]{4}{*}{$2 \cdot 25$} & 0 & 0 & $78 \cdot 3$ & 110 & 77 & 75 & $2 \cdot 2$ & 16 \\
\hline & & 200 & 15 & $3 \cdot 1$ & ND & 99 & ND & & \\
\hline & & 250 & 15 & 1.9 & ND & 99 & ND & & \\
\hline & & 300 & 15 & 1.8 & ND & 99 & ND & & \\
\hline & \multirow[t]{4}{*}{3.75} & 0 & 0 & $79 \cdot 3$ & $5 \cdot 2$ & 76 & 88 & 2.0 & 22 \\
\hline & & 250 & 15 & $2 \cdot 3$ & ND & 99 & ND & & \\
\hline & & 300 & 15 & 1.7 & ND & 99 & ND & & \\
\hline & & 350 & 15 & 1.4 & ND & 100 & ND & & \\
\hline
\end{tabular}

\footnotetext{
${ }^{a} \mathrm{ND}-$ not determined.
} 
Table 6. Experiment 4 -change in TP or total filterable $P$ after treatment with lime kiln dust with or without physico-chemical treatment using ferric sulphate $\left(\mathrm{Fe}^{3+}\right)$ or $\mathrm{Ca}(\mathrm{OH})_{2}(\mathrm{Ca})$ as the primary flocculant and characteristics of settled solids after phase 2

\begin{tabular}{|c|c|c|c|c|c|c|c|c|c|}
\hline \multirow[t]{3}{*}{ Phase 1} & \multirow{3}{*}{$\begin{array}{l}\text { Phase } 2 \\
\text { Lime kiln } \\
\text { dust dose } \\
\left(\mathrm{g} \mathrm{litre}^{-1}\right)\end{array}$} & \multicolumn{2}{|c|}{ Phase 3} & \multirow{3}{*}{$\begin{array}{c}\mathrm{TP} \\
\left(\mathrm{mg} \mathrm{litre}^{-1}\right)\end{array}$} & \multirow{3}{*}{$\begin{array}{c}\text { Total } \\
\text { filtrable } \mathrm{P} \\
\left(\mathrm{mg} \mathrm{litre}^{-1}\right)\end{array}$} & \multirow{3}{*}{$\begin{array}{c}\text { Decrease } \\
\text { in TP } \\
(\%)\end{array}$} & \multirow{3}{*}{$\begin{array}{c}\text { Decrease } \\
\text { in total } \\
\text { filtrable P } \\
\quad(\%)\end{array}$} & \multirow{2}{*}{\multicolumn{2}{|c|}{$\begin{array}{c}\text { Characteristics of } \\
\text { solids produced in } \\
\text { phase } 2\end{array}$}} \\
\hline & & \multirow{2}{*}{$\begin{array}{c}\text { Primary } \\
\text { flocculant } \\
\text { dose }^{a} \\
\left.(\mathrm{mg} \mathrm{litre})^{-1}\right)\end{array}$} & \multirow{2}{*}{$\begin{array}{c}\text { Poly } \\
\text { electrolyte } \\
\text { dose } \\
\left(\mathrm{mg} \mathrm{litre}^{\mathrm{l}}\right)\end{array}$} & & & & & & \\
\hline & & & & & & & & $\underset{\substack{\text { content } \\
(\%)}}{P}$ & $\begin{array}{c}\text { Neutralising } \\
\text { value } \\
(\%)\end{array}$ \\
\hline \multirow[t]{29}{*}{ Recycle } & \multirow{10}{*}{0} & & & 265 & 45 & & & & \\
\hline & & 0 & 0 & 102 & 29 & 61 & 36 & $2 \cdot 6$ & 1 \\
\hline & & $5000 \mathrm{Ca}$ & 10 & $7 \cdot 5$ & $\mathrm{ND}^{b}$ & 97 & ND & & \\
\hline & & & 20 & $8 \cdot 0$ & ND & 97 & ND & & \\
\hline & & $10000 \mathrm{Ca}$ & 10 & $3 \cdot 1$ & ND & 99 & ND & & \\
\hline & & & 20 & $3 \cdot 4$ & ND & 99 & ND & & \\
\hline & & $200 \mathrm{Fe}$ & 10 & 8.0 & ND & 97 & ND & & \\
\hline & & & 20 & $8 \cdot 7$ & ND & 97 & ND & & \\
\hline & & $400 \mathrm{Fe}$ & 5 & $4 \cdot 2$ & ND & 98 & ND & & \\
\hline & & & 10 & 3.7 & ND & 99 & ND & & \\
\hline & \multirow[t]{9}{*}{0.75} & 0 & 0 & 93 & 16 & 65 & 65 & $2 \cdot 8$ & 8 \\
\hline & & $5000 \mathrm{Ca}$ & 10 & 8.0 & ND & 97 & ND & & \\
\hline & & & 20 & $8 \cdot 8$ & ND & 97 & ND & & \\
\hline & & $10000 \mathrm{Ca}$ & 10 & $4 \cdot 1$ & ND & 99 & ND & & \\
\hline & & & 20 & $4 \cdot 2$ & ND & 98 & ND & & \\
\hline & & $200 \mathrm{Fe}$ & 10 & 8.9 & ND & 97 & ND & & \\
\hline & & & 20 & $9 \cdot 2$ & ND & 97 & ND & & \\
\hline & & $400 \mathrm{Fe}$ & 5 & $3 \cdot 5$ & ND & 99 & ND & & \\
\hline & & & 10 & 3.0 & ND & 99 & ND & & \\
\hline & \multirow[t]{9}{*}{$2 \cdot 25$} & 0 & 0 & 80 & 13 & 70 & 71 & $2 \cdot 3$ & 19 \\
\hline & & $5000 \mathrm{Ca}$ & 10 & $11 \cdot 7$ & ND & 96 & ND & & \\
\hline & & & 20 & $12 \cdot 5$ & ND & 95 & ND & & \\
\hline & & $10000 \mathrm{Ca}$ & 10 & $5 \cdot 0$ & ND & 98 & ND & & \\
\hline & & & 20 & 4.9 & ND & 98 & ND & & \\
\hline & & $200 \mathrm{Fe}$ & 10 & 9.9 & ND & 96 & ND & & \\
\hline & & & 20 & $10 \cdot 1$ & ND & 96 & ND & & \\
\hline & & $400 \mathrm{Fe}$ & 10 & $3 \cdot 7$ & ND & 99 & ND & & \\
\hline & & & 20 & 3.6 & ND & 99 & ND & & \\
\hline & $3 \cdot 75$ & 0 & 0 & 76 & 14 & 71 & 68 & $2 \cdot 0$ & 26 \\
\hline
\end{tabular}

${ }^{a}$ Ca addition is $\mathrm{mg}$ litre ${ }^{1}$ of $\mathrm{Ca}(\mathrm{OH})_{2}$ whereas $\mathrm{Fe}$ addition is $\mathrm{mg}$ litre ${ }^{1}$ of $\mathrm{Fe}^{3+}$.

${ }^{h} \mathrm{ND}$ - not determined

that the organic matter coated the lime particles (Inskeep \& Bloom, 1986) and hence slowed or stopped the reaction with $\mathrm{P}$. Total $\mathbf{P}$ includes dissolved, colloidal and biomass $P$. Biomass $P$ will react with lime only after death of microorganisms and subsequent decomposition of microbial tissues. This could partly explain why TP remained constant after treatment with lime. Alternatively, TP may have remained constant after lime treatment because total filterable $\mathrm{P}$ was converted to a solid form, some of which settled with other particles (biomass P), and some of which remained suspended in solution to contribute to TP.

Increasing lime dosage rates did not improve TP removal greatly, but did improve total filterable $P$ removal (Tables 4-6). With increased settling time, some of the suspended particles settled and increased the removal of total $P$ (Fig. 5). Unlimited settling time or physical treatment to remove suspended particulates would be represented by total filterable $P$ (Fig. 5). Increasing the settling time is not always a practical option, and there is evidence suggesting that some previously settled P-rich lime particles can be resuspended over longer periods of time (Payne, 1986b). Other disadvantages with long settling periods are that large and relatively quiescent ponds would be required to remove small particles. In the authors' experiments, low effluent: lime ratios increased the time of settling (Fig. 6) because the lime and effluent flocculated completely, causing the flocs to settle slowly after rapid initial settling. This behaviour is probably a function of the dimensions of the settling vessels used and the low effluent:lime ratios causing high concentrations of flocs which could not settle independently of one another. The slow settling phase may also have occurred as flocs were compressed under the weight of overlying flocs. While low effluent: lime ratios resulted in satisfactory $P$ removal from non-recycled effluent, it would not be an efficient use of the lime source for effluent treatment. In these experiments lime residues resulting from mixing piggery effluent at low effluent:lime ratios had lower $P$ contents and higher neutralising values than residues resulting from higher effluent: lime ratios (Tables 4-6). The choice of lime source and dosage rate therefore has implications not only for the efficiency and cost effectiveness of $\mathrm{P}$ removal but also for the subsequent re-use of lime residues on agricultural land.

Hydrated lime was more efficient per unit lime dose than kiln dust at removing $\mathbf{P}$ from ortho-phosphate 
solutions and effluent but lime kiln dust was more cost effective at removing $P$ from piggery effluent. One reason for this was that higher $\mathrm{pH}$ was maintained in the lime/ortho-phosphate mixture than in the lime/ effluent mixture at the same dosage rate (Figs 2 and 4).

Use of the physico-chemical treatment process could be prohibited by the cost of primary flocculant or residual aluminium in alum treated effluent if the treated waters are to be used for irrigation purposes on acidic soils. Aluminium levels were sufficiently high $(22-52 \mu \mathrm{m})$ to cause toxicity problems in plants, if the $\mathrm{pH}$ was low enough (Ritchie, 1989). The aluminium was not in a toxic form in the treated effluent because the $\mathrm{pH}$ was neutral; however, it may be altered to a toxic form in the soil if the soil $\mathrm{pH}$ was low enough. Solutions to this problem may lie in the use of other primary flocculants (e.g. hydrated lime or lime kiln dust) or in the use of cheaper ferric sources such as ferric sulphate used in experiment 4.

Recycling piggery effluent before treatment contributed to $P$ removal from the effluent by increasing the $P$ content of the solids removed by screening from 0.4 to $1.4 \% \mathrm{P}$. Settling without lime prior to any further physical or chemical treatment also decreased both total filterable and TP concentrations. Total P and total filterable $P$ decreased by up to 69 and $36 \%$, respectively, from settling alone (Tables 5 and 6). This compares favourably with other work (Gray et al., 1991) which suggested that soluble $\mathrm{P}$ decreased by up to $44 \%$ when a $2-3 \mathrm{~h}$ sedimentation time followed conventional screening.

It should be noted that it is misleading to assess methods of effluent treatment by considering only the percentage of $P$ removed. The final $P$ concentration of the treated effluent is equally important because a high percentage $P$ removal may still result in final $P$ concentration that can cause eutrophication of waterways. In addition, it is equally as important to decrease the volume of effluent discharged as it is to decrease the $\mathrm{P}$ concentration. A decrease in the volume should reduce effluent treatment costs and decreasing both the volume and concentration will lower the quantity of $\mathbf{P}$ exported.

In conclusion, physico-chemical treatment subsequent to settling with or without lime greatly improved the clarity of treated effluent and decreased its TP concentration by more than $95 \%$. The decrease in $\mathrm{P}$ did not depend on lime addition in phase 2 , hence the treatment procedure could be shortened to include only physicochemical treatment (phase 3 ). This would decrease both establishment and running costs.

Recycling effluent (phase 1) before treatment would minimise water consumption and in these experiments contributed to $\mathbf{P}$ removal from the liquid effluent. If effluent is not recycled as part of a waste management strategy, the volume of effluent requiring disposal is much greater and hence larger areas of land to house settling ponds are necessary. Other methods of removing P-rich suspended lime particles, such as the physicochemical treatment method employed here could remove the need for large settling ponds and large tracts of land associated with them.

\section{ACKNOWLEDGEMENTS}

The authors acknowledge the co-operation and enthusiasm of G. Fitzpatrick and family, Baconhaven Piggery, Baldivis WA; G. Crook; W. Hinchcliffe (formerly of Golconda Pty Ltd); M Kitney (formerly of Golconda Pty Ltd, now of Kellown Park Pty Ltd).

\section{REFERENCES}

AOAC (1984). Methods of Analysis (12th edn). Association of Official Analytical Chemists, Washington DC, USA.

APHA (1978). Standard methods for the examination of water and wastewater (14th edn.). American Public Health Association, New York, USA.

Dougan, W. K. \& Wilson, A. L. (1974). The absorptiometric determination of aluminium in water. A comparison of some chromogenic reagents and the development of an improved method. Analyst, 99, 413-30.

EPA (1990). Review of Industrial Wastewater Treatment Technologies. Environmental Protection Authority of Western Australia and Sinclair Knight and Partners, Australia.

Gray, K. R., Uvarkin, A. V. \& Biddlestone, A. J. (1991). Purification of wastewater from industrial pig farms in the USSR. J. Agric. Engng Res., 49, 21-31.

Hanson, W. C. (1950). The photometric determination of phosphorus in fertilizers using the phosphovanadomolybdate complex. J. Sci. Food Agric., 1, 172.

Inskeep, W. P. \& Bloom, P. R. (1986). Kinetics of calcite precipitation in the presence of water soluble organic ligands. Soil Sci. Soc, Am. J., 50, 1167-72.

John, M. K. (1970). Colorimetric determination of phosphorus in soil and plant materials with ascorbic acid. Soil Sci., 109, 214-20.

Payne, R. W. (1986a). Characteristics of faeces from institutional and commercial piggeries. Agric. Wastes, 16, 1-11.

Payne, R. W. (1986b). Removal of phosphorus from piggery effluents. In Proceedings of the Biennial Conference on Agricultural Engineering. Roseworthy Agricultural College, Roseworthy, August, 24-28, 1986.

Raper, W. G. C. (1983). Water pollution-sewage-recycling in Phosphorus in Australia, ed. A. B. Costin \& C. H. Williams. Centre for Resource and Environmental Studies, Australian National University, Canberra, Australia, 1983.

Ritchie, G. S. P. (1989). The chemical behaviour of aluminium hydrogen and manganese in acid soils. In Soil Acidity and Plant Growth, ed. A. D. Robson. Academic Press, Sydney, Australia, pp. 1-59.

Sas, H. (1989). Lake Restoration by Reduction of Nutrient Loading. ed. H. Sas. Academia Verlag. Hans Richarz Publikations-Service, 5205 Sankt Augusin 1, Austria.

Weaver, D. M. \& Ritchie, G. S. P. (1987). The effectiveness of lime-based amendments and bauxite residues at removing phosphorus from piggery effluent. Environ. Pollut., 46, 163-75. 